\title{
NILAI STRATEGIS GOOD CITIZEN SEBAGAI UPAYA PENINGKATAN KUALITAS PEMBANGUNAN PEMUDA DI KALIMANTAN BARAT
}

\author{
Hardi Alunaza SD ${ }^{1}$, Mentari ${ }^{2}$ \\ ${ }^{1}$ Program Studi Hubungan Internasional, Universitas Tanjungpura, Indonesia \\ 1Email: hardi.asd@fisip.untan.ac.id \\ ${ }^{2}$ Program Studi Sosiologi, Universitas Tanjungpura, Indonesia \\ 2Email:mentarihutiya@gmail.com
}

\begin{abstract}
ABSTRAK
Tulisan ini bertujuan untuk mendeskripsikan nilai-nilai strategis good citizen dalam peningkatan kualitas pembangunan pemuda di Kalimantan Barat. Penelitian ini dilaksanakan dengan menggunakan pendekatan kualitatif deskriptif. Sumber datanya adalah studi kepustakaan dan dianalisis menggunakan model analisis Miles Huberman. Temuan penelitian menunjukkan bahwa nilai strategis good citizen yang bisa dijadikan acuan dalam upaya peningkatan pembangunan pemuda di Kalimantan Barat adalah (1) good intelligence yang tercermin dari open minded, integritas diri, dan berhati seorang hamba; (2) good responsibility sebagai esensi dasar peningkatan kualitas pembangunan pemuda dan (3) good manner sebagai penopang perbaikan kualitas hidup pemuda. Berdasarkan temuan tersebut disarankan: (1) peningkatan kualitas pembangunan di Kalimantan Barat harus memperhatikan aspek pendidikan yang berdampak positif terhadap kualitas diri pemuda; (2) Selain aspek pendidikan, pemuda juga harus dibekali dasar-dasar kepemimpinan untuk membentuk individu yang bertanggung jawab; (3) Serta memperhatikan aspek yang sangat krusial dari good citizen yakni memiliki etika yang baik sebagai tujuan utama yang sesuai dengan nilai-nilai Pancasila.
\end{abstract}

Kata Kunci: Good intelligence; Good responsibility; Good manner; Good citizen.

\begin{abstract}
This research is attempted to describe the strategic values of good citizens in improving the quality of youth development in West Kalimantan. This research was conducted using a descriptive qualitative approach. The data source is literature study and analyzed using the Miles Huberman analysis model. The research findings show that the strategic value of good citizen which can be used as a reference in efforts to increase youth development in West Kalimantan are (1) good intelligence which is reflected in open mindedness, self-integrity, and a servant's heart; (2) good responsibility as the basic essence of improving the quality of youth development and (3) good manner as a support for improving the quality of youth life. Based on these findings, it is suggested: (1) increasing the quality of development in West Kalimantan must pay attention to aspects of education that have a positive impact on the quality of youth; (2) In addition to the educational aspect, youth must also be equipped with the basics of leadership to form responsible individuals; (3) As well as paying attention to a very crucial aspect of a good citizen, namely having good attitude as the main goal in accordance with the values of Pancasila.
\end{abstract}

Keywords: Good intelligence; Good responsibility; Good manner Good citizen. 


\section{PENDAHULUAN}

Pada tahun 2018, kaum millennial di Kalimantan Barat yang memiliki rentang usia 17-37 tahun tercatat 50\% tingkat pendidikannya adalah SMP kebawah. Hal ini merupakan permasalahan yang sangat memprihatinkan. Jumlah penduduk miskin terbanyak adalah di daerah Ketapang dan Melawi (Tribun Pontianak, 2018). Kawasan perbatasan masih menjadi isu hangat untuk diperbincangkan, khususnya jika membahas mengenai kualitas sumber daya manusia. Selain karena masih memiliki stigma sebagai daerah yang tertinggal, kawasan perbatasan juga sering kali memiliki banyak kendala dalam akses sehingga pembangunan sumber daya manusia khususnya pemuda menjadi terhambat. Masalah sumber daya manusia tetap menjadi ujung pangkal dari semua permasalahan yang ditemukan di kawasan perbatasan Indonesia-Malaysia (Adityo \& Alunaza, 2019).

Padahal pembangunan pemuda merupakan salah satu fokus dan menjadi agenda strategis Indonesia dalam rangkaian mewujudkan dan mempersiapkan generasi masa depan yang berdaya saing untuk menopang pembangunan Indonesia secara keseluruhan (Said, 2016). Tujuan dari pembangunan berkelanjutan telah menempatkan pemuda sebagai aktor strategis yang dinilai mampu memiliki peran yang besar dalam pembangunan Indonesia yang berkelanjutan (ksp.go.id).

Jika melihat data yang ada, Indeks Pembangunan Pemuda (IPP) Kalimantan Barat berada pada posisi 28 dengan indeks pada tahun 2016 sebesar 47,5 poin. Faktor kehamilan remaja yang meningkat menjadi penyebab penurunan tajam dari angka Sembilan menjadi lima poin. Seharusnya provinsi ini memiliki indeks pembangunan pemuda yang lebih besar lagi mengingat lima indikator yang digunakan dalam menilai IPP yakni pendidikan, ketersediaan lapangan pekerjaan, tingkat kesehatan dan kesejahteraan, partisipasi kepemimpinan, serta gender dan diskriminasi mengalami peningkatan dan perbaikan. Tidak banyak provinsi yang mengalami kenaikan dan peningkatan sekaligus. Namun, di Kalimantan Barat kenaikan tersebut berbanding terbalik dengan peningkatan kehamilan remaja. Angka kehamilan remaja di Kalimantan Barat naik pesat dari lima persen menjadi $23 \%$ di tahun 2016 sesuai dengan tampilan data berikut:

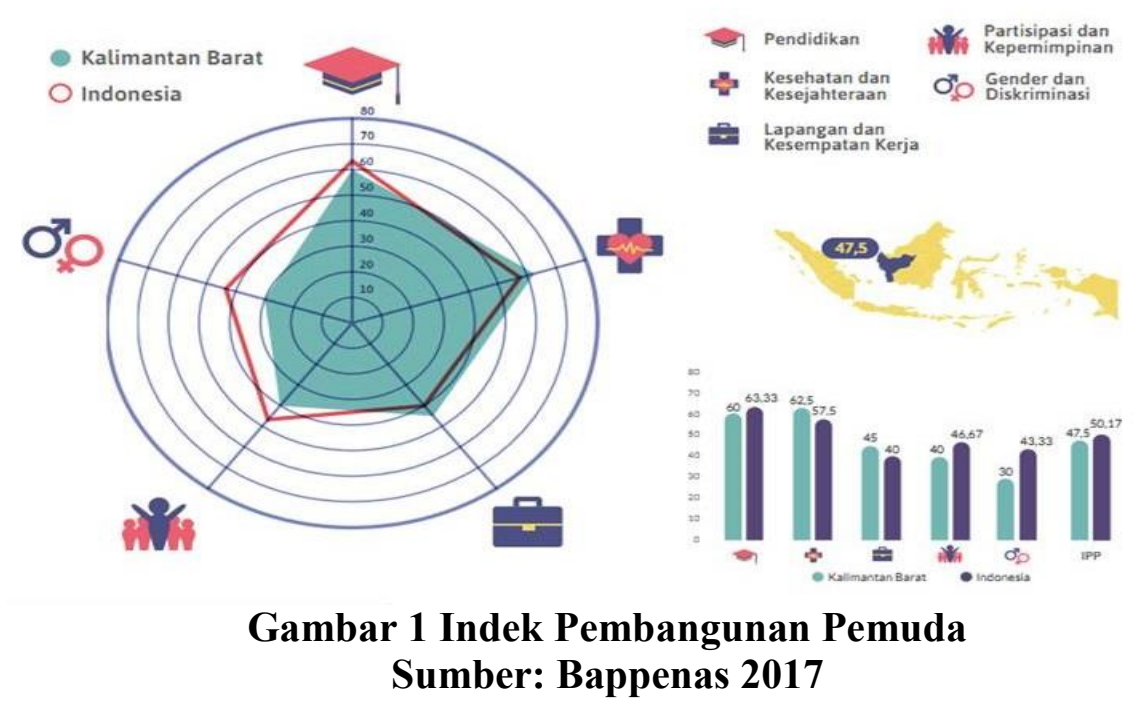

Hardi Alunaza SD dan Mentari, Nilai Strategis Good Citizen Sebagai Upaya Peningkatan Kualitas Pembangunan Pemuda di Kalimantan Barat 
Masa depan bangsa Indonesia dapat ditaksir dengan melihat bagaimana potensi pemuda yang dimiliki dan usaha yang dibangun untuk memperbaiki indeks pembangunan pemuda di masa depan. Terutama dengan memperhatikan bagaimana potensi yang dimiliki oleh pemuda di daerah perbatasan. Sebab, sebagaimana mandat Presiden Joko Widodo untuk membangun Indonesia maju adalah dengan melakukan implementasi terhadap kebijakan nawa cita (Syam, 2015). Kebijakan ini berfokus pada 9 agenda prioritas pembangunan masa depan bangsa Indonesia, salah satunya adalah fokus membangun dari kawasan perbatasan. Jika pemuda di perbatasan sudah memiliki potensi yang baik, maka Indonesia akan menjadi Negara yang memiliki indeks pembangunan pemuda yang baik juga (Tribun Pontianak, 2019). Mengingat bahwa selama ini yang menjadi tantangan dalam pembangunan adalah daerah perbatasan yang sering diberi julukan sebagai daerah tertinggal.

Saat ini komposisi pemuda di Indonesia didominasi oleh penduduk muda yang besar. Antara rentang usia 16-30 tahun sekitar 60 juta jiwa. Jumlah penduduk pemuda yang besar tersebut dapat menjadi kekuatan dan juga dapat menjadi kelemahan. Hal ini bergantung bagaimana pemuda dipandang, diperlakukan dan dipersiapkan untuk menghadapi pembangunan masa depan bangsa. Bonus demografi, khususnya untuk pemuda di daerah perbatasan dapat digunakan untuk pengembangan segala aspek (Bismar, 2016). Termasuk pengembangan hal yang paling krusial yakni pendidikan, sosial politik, dan kualitas kepemimpinan. Dengan kata lain, manfaat dari bonus demografi tergantung kepada apa yang diinvestasikan kepada generasi muda. Sehingga, kualitas pemuda menjadi daya tawar tersendiri untuk memajukan pembangunan bangsa ini (Bappenas, 2017).
Berdasarkan permasalahan yang sudah disebutkan di atas, tulisan ini melihat adanya permasalahan mengenai apa yang harus dilakukan oleh generasi muda sebagai ujung tombak pembangunan di daerah perbatasan Kalimantan Barat. Dalam konteks ini, penulis menekankan mengenai potensi pemuda di perbatasan sebagai pengisi dan bagian dari besarnya sumber daya yang dimiliki Indonesia. Berdasarkan telaah yang penulis lakukan, belum ada tulisan langsung secara spesifik yang menjelaskan langsung mengenai nilai strategis pemuda dan pembangunan pemuda di Kalimantan Barat. Tulisan ini dibagi menjadi tiga bagian penting dalam menjelaskan bagaimana pemuda menjadi nilai strategis di kawasan perbatasan. Pertama, pemuda selalu diposisikan menjadi bagian yang sentral dari perubahan masyarakat, sehingga pemuda harus memiliki 3G yang pertama yaitu good intelegence. Kedua, peranan pemuda selalu diandalkan untuk menjawab tantang yang dihadapi masyarakat, maka pemuda harus memiliki sense good responsibility. Serta, pemuda selalu menjadi pusat perhatian dan contoh bagi masyarakat, oleh karena itu mereka harus memiliki good manners. Dalam tulisan ini, penulis melihat potensi good intelegence, good responsibility, dan good manner sebagai nilai strategis dari good citizen yang dapat diterapkan sebagai upaya untuk memperbaiki kualitas pembangunan pemuda di perbatasan yang akan dihubungkan dengan beberapa hal yang berhubungan dengan indikator pembangunan pemuda seperti yang sudah disebutkan sebelumnya. Tulisan ini menggunakan teori pemberdayaan pemuda dalam menjelaskan fenomena. Teori pemberdayaan menjelaskan mengenai upaya untuk memberikan kemampuan dan keberdayaan. Sedangkan proses pemberdayaan dalam konteks aktualisasi diri berkaitan dengan upaya untuk meningkatkan kemampuan individu dengan menggali segala potensi yang 
dimiliki oleh individu tersebut baik yang berhubungan dengan kemampuan keahlian (skill) atau pun pengetahuan (knowledge). Proses akan merujuk pada satu tindakan nyata yang dilakukan secara bertahap untuk mengubah kondisi masyarakat baik secara pengetahuan (knowledge), sikap dan perilaku (attitude), dan sadar terhadap kecakapan dan keterampilan yang baik (Sulistyani, 2004).

\section{METODE}

Pada dasarnya sebuah penelitian adalah kegiatan yang dilakukan untuk mencari jawaban terhadap pertanyaan bagaimana pemuda memiliki nilai strategis di kawasan perbatasan. Penelitian nilai strategis good citizen sebagai upaya peningkatan kualitas pembangunan pemuda di Kalimantan Barat ini termasuk penelitian deskriptif dengan pendekatan kualitatif. Penulis berusaha untuk mendeskripsikan keadaan objek serta permasalahan yang ada. Oleh karena itu, metode deskriptif diharapkan dapat mencapai tujuan penelitian, yaitu menggambarkan secara jelas fakta dan karakteristik objek yang dijelaskan secara tepat.

Penulis menggunakan metode pengumpulan data yang bersifat studi kepustakaan untuk lebih mengakuratkan penelitian dari sisi keilmuan. Metode ini dilaksanakan dengan topik permasalahan yang diangkat melalui penelitian terhadap buku, tulisan, artikel, dan hasil penelitian mengenai objek kajian yang diteliti. Selain itu, penulis juga mencari data yang relevan dengan penelitian ini dari media elektronik dengan sumber yang dapat dipercaya (reliable). Teknik analisa data yang digunakan dalam tulisan ini mengacu kepada Miles dan Huberman, dimana kegiatan analisis terdiri dari tiga alur kegiatan yang terjadi secara bersamaan, yaitu reduksi data, penyajian data, dan penarikan kesimpulan atau verifikasi (Sugiyono, 2011). Dalam menganalisa penelitian ini penulis menggunakan tiga tahapan yakni mengumpulkan data, pengolahan data, dan analisis. Untuk mempermudah penulis maka analisa data juga akan dilakukan bersamaan pada saat data terkumpul.

\section{HASIL DAN PEMBAHASAN \\ Nilai Strategis Good Intelegence Bagi Pemuda di Perbatasan}

Definisi mengenai good intelligence sendiri adalah kapasitas untuk memperoleh dan menerapkan ilmu pengetahuan. Mencakup di dalamnya adalah kemampuan untuk mengambil manfaat dari pengalaman masa lalu, bertindak dengan sengaja, kemampuan memecahkan masalah, dan beradaptasi dengan situasi baru. Bagaimana hal tersebut dapat menjadi nilai strategis bagi pemuda? Sebab, kecerdasan akan menjadi dasar bagi pemikiran yang terbuka (open minded). Pemikiran yang terbuka menjadi nilai penting bagaimana pemuda dapat menjadi sumber perubahan yang positif. Dalam buku the image: knowledge in life and society dijelaskan bahwa kecerdasan dan pemikiran yang terbuka didapat dari proses belajar yang di dalamnya terjadi proses perbaikan kualitas diri untuk memiliki kearifan dan kemampuan menyelesaikan masalah (Yosita, 2016).

Maka, pendidikan dan kecerdasan intelektual dipandang perlu dan menjadi aspek krusial bagi perubahan yang dikehendaki. Hal tersebut diperlukan untuk membangun generasi muda yang memiliki produktivitas dan kualitas sumber daya manusia yang baik (Subandowo, 2017). Contoh yang sangat jelas sebagai pengaruh dari kecerdasan intelektual dan open minded adalah munculnya kreativitas dari generasi muda untuk menciptakan lapangan pekerjaan yang dibutuhkan oleh masyarakat luas. Seperti munculnya beberapa generasi millennial dalam jajaran menteri kabinet Indonesia Maju. Sudah sangat jelas, bahwa good intelligence memiliki nilai yang 
begitu penting agar dapat meningkatkan kualitas hidup pemuda. Menjadi pemimpin akan sangat efektif jika didasarkan pada tiga fondasi inti yakni integritas diri, hati hamba, dan mau menjadi pelayan yang baik untuk masyarakat (Hamdani, 2013).

Pemuda dapat menjadi pemimpin yang besar jika memperlihatkan integritas diri dengan memberikan dedikasi pada pencapaian tujuan demi kepentingan rakyat (Antonius, 2014). Tentu hal tersebut tidak didapat tanpa proses. Ada banyak proses yang harus dilewati untuk mendapatkan integritas diri, salah satu yang paling utama adalah pendidikan atau dalam tulisan ini dikenal dengan kecerdasan intelektual (Rustiono, 2017). Melalui pendidikan dan kecerdasan intelektual yang didapatkan, pemuda dapat menjalankan kehidupan yang seimbang dan utuh serta dapat memberikan kesempatan kepada masyarakat.

Fondasi inti yang kedua adalah berhati seorang hamba. Maksud dari berhati seorang hamba adalah, pemuda dapat menjadi pemimpin yang mampu membimbing, memberdayakan, menginspirasi orang lain agar melakukan lebih dan mendapatkan lebih. Memiliki hati seorang hamba berarti menjelaskan kepada masyarakat benarbenardihargai dandipedulikan. Selanjutnya, unsur yang tidak kalah penting adalah pelayanan. Hasil dari proses belajar dan mendapatkan kecerdasan intelektual yang baik dapat tercermin dari komitmen untuk lebih dan senantiasa menghargai orang lain. Maka, pemuda sebagai generasi terdidik dan memiliki pemikiran yang terbuka akan selalu berusaha menginvestasikan waktu dan kemampuan untuk mengembangkan, memelihara, dan menjaga kestabilan pembangunan bangsa. Baik itu dalam jangka pendek atau pun jangka panjang.

Kecerdasan yang dimiliki oleh pemuda memainkan peran penting bagi berbagai indeks pembangunan. Kecerdasan yang baik juga memiliki peran yang sangat penting untuk menentukan arah pencapaian bangsa Indonesia di masa depan. Kecerdasan intelektual tidak hanya diperlukan bagi pemimpin, tetapi juga berlaku bagi semua elemen masyarakat sehingga kehidupan menjadi terorganisir dan tujuan bersama di masa depan dapat dicapai. Kecerdasan intelektual dapat dipergunakan sebagai fondasi dasar bagi pemuda di Kalimantan Barat untuk mengisi perubahan positif dan menghapuskan pelanggaran atau penyimpangan yang terjadi selama ini yang sangat berpengaruh kepada peningkatan angka kualitas pembangunan pemuda di kawasan perbatasan. Salah satu penyimpangan yang dapat diperbaiki dengan pendidikan adalah kasus pernikahan dini yang semakin marak terjadi di kalangan anak muda. Pendidikan memiliki peran besar untuk dapat menaikkan angka pembangunan pemuda dengan mengajarkan pemuda untuk berpikir terbuka bahwa sudah semestinya globalisasi dapat di filter untuk mewujudkan kualitas yang pendidikan yang signifikan dan penekanan mengenai pendidikan yang berkarakter untuk mencerdaskan kehidupan bangsa (Aryni, 2015).

\section{Makna Good responsibility Bagi Kemajuan Pembangunan}

Jika menilik permasalahan yang sering terjadi di negeri ini, berdasarkan fakta yang saat ini kita lihat di lapangan, bangsa ini minim memberikan kesempatan kepada pemuda untuk terlibat dalam ranah yang strategis. Sehingga yang menjadi pemandangan dalam kehidupan keseharian adalah banyaknya pemimpin yang terjerat kasus korupsi, pemimpin yang tidak amanah serta oknum yang mengambil kesempatan untuk memperkaya diri (Tim Spora, 2015). Pemuda khususnya mahasiswa padahal memiliki peran yang sangat signifikan untuk terlibat dan pencegahan tindakan korupsi sejak dini. Tindakan pencegahan perilaku korupsi bagi pemuda dapat dilakukan dengan memberikan pengetahuan, 
mengajari pemuda bagaimana harus bersikap, dan melakukan implementasi nilainilai pendidikan. Implementasi nilai-nilai pendidikan bagi pemuda sangat dibutuhkan agar terciptanya pemuda sebagai ujung tombak perubahan dan berperan sebagai warga Negara yang baik (good citizen) yang dapat melindungi bangsa Indonesia dari bahaya korupsi (Permatasari dkk, 2019). Indonesia khususnya di daerah perbatasan hari ini masih kekurangan tokoh-tokoh muda yang berpengaruh dan memegang peranan besar demi kemajuan bangsa. Hal ini terjadi karena tidak adanya kemauan untuk membangun dan kurangnya perhatian terhadap para pemuda agar dapat tampil menjadi generasi penerus bangsa yang memiliki sense good responsibility.

Kaitannya dengan good intelligence adalah bahwa tanggung jawab yang baik itu dilahirkan dengan melalui proses panjang. Salah satunya adalah melalui pendidikan. Keterlibatan sektor pendidikan formal memiliki kedudukan yang sangat strategis dalam mendukung pemuda memberantas tindak pidana korupsi di Indonesia. Upaya menumbuhkan jiwa tanggung jawab bagi generasi muda adalah dengan terlebih dahulu mencegah berkembangnya mental korupsi di kalangan pemuda (Kurniawan \& Setiyowati, 2018). Jika dari segi pendidikan atau kecerdasan intelektual sudah baik, maka pemuda akan memiliki tiga moral dasar yakni integritas diri, berhati hamba, dan mau melayani ketika tampil sebagai pemimpin. Indonesia kekurangan pemuda yang memiliki dimensi tersebut.

Apalagi di daerah perbatasan yang notabene-nya adalah daerah tertinggal, dimana pemuda yang ada lebih berorientasi pada hasil daripada proses. Membangun dimensi tanggung jawab yang baik ini di daerah perbatasan menjadi tidak mudah, karena selalu diharapkan dengan pemuda yang memiliki pola pikir pragmatis dan tidak terbuka (Baguna, 2019). Padahal, good responsibility adalah dasar bagi bangsa Indonesia untuk dapat mencapai tujuan pembangunan pemuda di masa depan. Sebab pemuda adalah tolak ukur maju atau mundurnya suatu bangsa. Lalu, bagaimana jika good intelligence dan good responsibility tidak dapat diwujudkan oleh pemuda di perbatasan. Apakah kemudian misi untuk meningkatkan indeks pembangunan pemuda yang dimulai dari kawasan perbatasan akan semakin membaik?

Sebagai salah satu penopang dalam meningkatkan nilai saing pembangunan pemuda di Kalimantan Barat sebagai daerah yang berada di perbatasan adalah dengan membentuk kecakapan partisipatif yang menonjolkan nilai kehidupan yang bertanggung jawab dalam kehidupan berbangsa dan bernegara. Hal tersebut yang akan menjadi pendukung bagi terciptanya generasi muda yang demokratis dan memiliki komitmen menjaga persatuan bangsa Indonesia, kehidupan yang menjunjung nilai-nilai toleransi, dan bertanggung jawab. Tindakan lainnya yang dapat bermanfaat dalam meningkatkan pembangunan pemuda adalah dengan berperilaku jujur, menghormati hak orang lain, bekerja keras (Suhardiyansyah dkk, 2016). Dimensi good responsibility atau tanggung jawab menjadi penting bagi peningkatan kualitas pembangunan pemuda karena berhubungan dengan pelaksanaan peranan baik secara individu maupun peranan dalam kehidupan sosial. Sebagai individu, pemuda harus mengetahui peran dan tanggung jawab yang diemban dan dilaksanakan karena bersinergi dengan tanggung jawab sosial dan tanggung jawab kepada lingkungan serta tanggung jawab terhadap bangsa dan Negara (Rohani, 2013).

\section{Good manners Sebagai Penentu Pembangunan Pemuda}

Seperti yang tertuang dalam sila kedua Pancasila 'Kemanusiaan yang adil 
dan beradab', bahwa etika adalah gambaran diri seseorang. Jika seseorang memiliki etika yang baik, maka ia akan berpikir sebelum berbuat atau berkata (Kamtono, 2019). Nilai yang termaktub dalam poin good manners adalah memperhatikan dan mampu mengontrol terhadap apa yang akan dikerjakan dan dibicarakan. Pemuda yang terdidik dan bermoral baik, serta memiliki tanggung jawab pasti tahu bahwa penyimpangan yang hendak dilakukan adalah hal yang tidak baik. Agar dapat membentuk generasi muda yang bermoral baik, diperlukan adanya integrasi antara pendidikan, nilai-nilai demokrasi, dan pengetahuan mengenai kewarganegaraan yang baik. Hal tersebut harus sesuai dengan landasan Pancasila dan mengandung esensi cinta tanah air dan bela Negara. Pengembangan karate pemuda yang bermoral di Kalimantan Barat harus didasarkan pada moralitas yang baik (Syamsul dkk, 2017). Karena segala bentuk penyimpangan yang dilakukan oleh pemuda disebabkan tidak adanya moral dan kurangnya pendidikan. Hal tersebut tidak sesuai dengan tujuan dari pembentukan dan proses pembangunan bangsa ini yaitu 'untuk mencerdaskan kehidupan bangsa dan mewujudkan kesejahteraan umum'. Adil dalam arti bahwa pemuda mendapatkan porsi yang harus mereka terima untuk memperbaiki dan meningkatkan indeks pembangunan.

Jika kemudian pemuda di perbatasan berusaha untuk lari dari tanggung jawab untuk menyelesaikan proses belajar, itu artinya mereka tidak memiliki etika yang baik. Sebab partisipasi keikutsertaan di sekolah dan perguruan tinggi adalah indikator dari keberhasilan pendidikan yang menjadi penilaian dalam peningkatan indeks pembangunan pemuda. Pemuda yang memiliki etika yang baik adalah pemuda yang sadar bahwa pergaulan bebas dan kebiasaan mengonsumsi obatobatan terlarang adalah tidak baik. Sebab itu merusak arti kata beradab. Esensi dari good manners juga akan hilang jika pemuda enggan untuk bekerja, acuh untuk memiliki soft skill, tidak mau menyampaikan pendapat politik, serta tidak mencoba untuk bergabung dalam suatu organisasi. Ketimpangan yang terjadi di tengah-tengah masyarakat kita saat ini adalah karena pemuda sudah terlalui dibuai oleh kemajuan jaman. Globalisasi dipandang menjadi dinding pemisah antara rasa peduli dan sikap pemuda yang kerap kali menomor duakan etika dan moral. Hal tersebut menjadi momok dan racun berbahaya terhadap perbaikan kualitas hidup bangsa ini.

Good manners dapat menjadi pelengkap bagi good intelligence dan good responsibility dalam menciptakan tatanan kehidupan pemuda yang lebih berdaya saing dan menjalankan kewajiban dengan penuh tanggung jawab. Selain karena merupakan bagian dari unsur pembentuk good citizen, tujuan akhir dan utama adalah terciptanya pemuda yang berbudi baik dan bermoral dan menjalankan tugas dan fungsi sebagai tombak perubahan dan perkembangan zaman. Bung Karno dahulu pernah mengatakan "Beri aku 10 pemuda, akan kuguncang dunia". Ternyata begitu besar harapan yang disampaikan oleh para pendiri bangsa ini kepada pemuda untuk terus bergerak dan menciptakan perubahan.

Generasi muda saat ini, khususnya yang berada di kawasan perbatasan harus mampu tampil sebagai generasi yang bergerak dan dapat menyikapi perkembangan jaman. Pemuda juga harus dapat terampil mengambil sisi positif dari perkembangan dan meninggalkan sisi negatifnya. Tentu dalam hal membangun dan menjadikan bangsa ini lebih baik di masa depan, pemuda harus beretika dan bermoral baik. Umar bin Khattab juga pernah mengisyaratkan sebuah pesan "setiap kali aku menemui masalah-masalah besar, yang kupanggil adalah pemuda". Isyarat yang sudah jelas 
terlihat bahwa pemuda memiliki potensi besar untuk meneruskan pembangunan bangsa. Apalagi jika ketiga komponen nilai strategis yakni kecerdasan intelektual, tanggung jawab, dan etika moral sebagai kunci (Jamaluddin \& Indriasari, 2011). Pasti kualitas pembangunan di kawasan perbatasan yang selama ini dianggap sebagai daerah tertinggal dapat diperbaiki dan ditingkatkan.

\section{SIMPULAN}

Kualitas sumber daya manusia di Kalimantan Barat masih membutuhkan peningkatan dengan adanya peran pemuda. Nilai good intelligence, good responsibility, dan good manner dapat digunakan untuk mencapai perbaikan indeks pembangunan pemuda di daerah perbatasan dan juga Indonesia. Aspek pendidikan, tanggung jawab, dan etika moral yang baik akan berdampak positif terhadap peningkatan kesejahteraan dan kesehatan. Di samping itu, good citizen juga sangat berhubungan dengan tanggung jawab dan etika moral. Ketika pemuda memiliki keduanya, sudah pasti pemuda akan lebih jeli dalam demokrasi, berpartisipasi dalam meningkatkan kualitas dan kepemimpinan serta mengurangi adanya diskriminasi dan kesenjangan sosial.

Hal ini menjadi cerminan bahwa pemuda di daerah perbatasan harus memiliki kecerdasan intelektual yang baik yang dapat membentuk pemikiran terbuka (open minded), dan diselaraskan dengan status pemuda sebagai pusat perubahan dan pembangunan Indonesia. Sudah barang tentu, proses perbaikan ini harus juga diiringi dengan menanamkan sikap tanggung jawab dan menjaga etika agar tujuan pembangunan dapat terlaksana dengan baik. Keberhasilan pemuda untuk menjadi ujung tombak bangsa ini akan selalu dipengaruhi oleh $3 \mathrm{G}$ yang sudah dijelaskan sebelumnya.

Melalui formulasi $3 \mathrm{G}$ tersebut, pemuda di daerah perbatasan dan Indonesia bisa menciptakan iklim pendidikan yang baik, kualitas kesejahteraan yang meningkat, lapangan pekerjaan dan kesempatan kerja yang terus bertambah, duduk dan menjabat sebagai pemimpin dengan kepercayaan dan tanggung jawab yang penuh, serta berkurangnya angka diskriminasi dan ketidakadilan di negeri ini. Sebagai penutup di bagian akhir tulisan ini, pemuda harus fokus menyiapkan, menunjang, dan memberikan pengaruh positif dengan memanfaatkan formulasi $3 \mathrm{G}$ agar dapat menjawab tantangan pembangunan di masa depan. Sebab bangsa Indonesia membutuhkan peran pemuda lewat kontribusi, gagasan cemerlang, ide, dan solusi untuk membawa bangsa ini menjadi Negara yang maju. Posisi tulisan ini hanya melihat bagaimana nilai pembangunan pemuda di Kalimantan Barat itu dapat diperbaiki dengan memperhatikan aspek pendidikan, tanggung jawab, dan etika moral. Hasil dari tulisan sejenis bisa jadi berbeda jika ditulis oleh penulis yang berbeda dan melihat dari sudut pandang yang berbeda pula.

\section{DAFTAR PUSTAKA}

Adityo, Darmawan \& Alunaza, Hardi. (2019). Kebijakan Nawa Cita Sebagai Dasar Pembangunan di Kawasan Perbatasan Kalimantan Barat. Laporan Hasil Penelitian Disampaikan Pada Pertemuan Nasional Asosiasi Sarjana Hubungan Internasional Indonesia. Tanjung Pinang: Universitas Maritim Ali Haji.

Arianto, Bismar. (2016). Optimalisasi Dana Desa: Upaya Alternatif Menyongsong Bonus Demografi Indonesia 20202030. Prosiding Seminar Nasional Fakultas Ilmu Sosial Ilmu Politik Universitas Lampung. Hal: 86.

Anonim. (2018). Anak Muda Berperan

Penting Sukseskan Pembangunan Berkelanjutan. Depok: Kantor Staf Presiden. 
Atosokhi Gea, Antonius. (2014). Integritas Personal dan Kepemimpinan Etis. Jurnal Humaniora Vol 5 (2). Hal: 953.

Ayu Widiyawati, Aryni. (2015). Pendidikan Karakter di Tengah Globalisasi: Epistemologi, Terminologi, dan Aksiologi Menghadapi MEA 2015. Prosiding Seminar Nasional Pendidikan Ekonomi Fakultas Keguruan dan Ilmu Pendidikan Universitas Jember. Hal: 23

Baguna, Paskalis. (2019). Pancasila and Trias Politica. Pontianak: Universitas Tanjungpura.

Hamdani, Mailani. (2013). Menumbuhkan Jiwa Kepemimpinan Generasi Muda Melalui Kewirausahaan (sebuah Kajian Teoritis). Jakarta: Universitas Terbuka.

Jamaluddin \& Indriasari, Rahayu. (2011). Pengaruh Kecerdasan Intelektual, Emosional, dan Spiritual Terhadap Etika Mahasiswa Akuntasi Fakultas Ekonomi Universitas Taduloko. Jurnal Pamator Vol 4 (1) Hal: 47.

Kamtono, Livia. (2019). Good manners in Society and Political Area. Pontianak: Universitas Tanjungpura.

Kurniawan, Wahyu \& Setiyowati, Rini. (2018). Penanaman Nilai-Nilai Pendidikan Antikorupsi Melalui Habitus Keteladanan di SMP Muhammadiyah Boarding School Yogyakarta. Jurnal Civic Hukum Vol 3 (1) Hal: 65.

Permatasari, M., Handayani, T., Budiono. (2019). Implementasi Nilai-Nilai Pendidikan Antikorupsi dalam Membentuk Good citizen pada Era Millenial. Jurnal Civic Hukum Vol 4 (1) Hal: 20

Rohani. (2013). Pembinaan Tanggung Jawab Warga Negara dalam Memecahkan Masalah-Masalah Sosial Melalui PendidikanKewarganegaraan Kemasyarakatan (Community Civics). Jurnal Edukasi Vol 11 (2) Hal: 225.
Rustiono. (2017). Zona Nyaman Baru Bernama Zona Integritas. Diakses melalui laman http://unnes.ac.id/ gagas an/zona-nyaman-barubernama-zona-integritas pada tanggal 2 November 2019 pukul 20.05 WIB.

Said, Ali \& Budianti, Indah. (2016). Potret Awal Tujuan Pembangunan Berkelanjutan di Indonesia. Jakarta: Badan Pusat Statistik.

Sardjoko, Subandi. (2017). Indeks Pembangunan Pemuda Indonesia. Jakarta: Bappenas.

Subandowo, M. (2017). Peradaban dan Produktivitas dalam Perspektif Bonus Demografi sertaGenerasiY danZ. Jurnal Sosio Humanika: Jurnal Pendidikan Sains Sosial dan Kemanusiaan Vol 10 (2) Hal: 192.

Sugiyono. (2011). Metode Penelitian Kualitatif Kuantitatif dan R \&D. Bandung: Alfabeta: 246.

Surya, Syam Syamsi. (2015). Nawa Cita Jokowi-JK dalam Paradigma Pembangunan Ekonomi. Surya Octagon Interdisciplinary Journal of Science \& Technology Vol 1 (1) Hal: 2. Syamsul, Y., Widodo, R., Tinus, A. (2017). PerananPendidikanKewarganegaraan (Pkn) dalam Pembentukan Moral Peserta Didik. Jurnal Civic Hukum Vol 2 (1) Hal: 40.

Syuhardiyansyah, YM., Budiono, Widodo, R. (2016). Implementasi Pendidikan Karakter Melalui Bidang Studi Pendidikan Kewarganegaraan. Jurnal Civic Hukum Vol 1 (1) Hal: 2.

Tim Spora. (2015). Kapita Selekta dan Beban Biaya Sosial Korupsi. Jakarta: Direktorat Pendidikan dan Pelayanan Masyarakat Kedeputian Bidang Pencegahan Komisi Pemberantasan Korupsi.

Teguh, Sulistiyani Ambar. (2004). Kemitraan dan Model-Model Pemberdayaan. Yogyakarta: Gava Media: 2 
Tribun Pontianak. (2018). Sumber Daya Manusia Tak Memadai, Kalbar Tak Bisa Maksimalkan Manfaat Investasi. Diakses melalui laman https://pontianak.tribunnews. com/2018/09/25/sumber-dayamanusia-tak-memadai-kalbar-takbisa-maksimalkan-manfaat-investasi pada tanggal 19 September 2020 pukul 06.10 WIB

Tribun Pontianak (2019). Midji: Saya Serius Bangun SDM Kalbar. Diakses melalui laman https://pontianak. tribunnews.com/2019/02/21/midjisaya-serius-bangun-sdm-kalbar pada tanggal 19 September 2020 pukul 06.10 WIB

Yosita, Lucy. (2016). Kepemimpinan Pemuda Indonesia, Apakah Akar Masalahnya? Jakarta: Kemenpora. 